\title{
Reform \& Exploration of Informatization Management Mechanism in Vocational Colleges
}

\author{
Cong Cheng \\ Information Center, Beijing Polytechnic College,Beijing,China,100042 \\ cong_cheng@vip.sohu.com
}

Key words: informatization management, informatization mechanism

\begin{abstract}
In recent years, the imperfect informatization management mechanism has severely shackled the development of vocational colleges. This paper proposed such creative ideas as reinforcement of CIO responsibilities, establishment of leader teams, improvement of examination and evaluation system, and clarification of business structure, etc. So as to accelerate the construction of their informatization.
\end{abstract}

\section{Introduction}

Since the vocational colleges are still at an exploratory stage for constructing their information mechanism, considerable problems abound, including unsound security system, faulty evaluation mechanism, unclear responsibility division between implementing units. Such problems,to a certain extent, hinder the progress of informatization, so that exploring an effective mechanism for vocational colleges is a top priority in their informatization research.

\section{Current Status of Informatization Mechanism of Vocational Colleges}

Lack of informatization leadership mechanism lead to a variety of malpractices. Nowadays, most vocational colleges rely on an information center (or network center) for their information construction and management; some even count on a secondary branch adhering to Publicity Department or a Party Office. In absence of the CIO leadership mechanism, the business departments are limited in their authority scope and overall planning ability, which makes it very difficult to guarantee an informatization of the strategic development of colleges; the lack of unified planning leads to uneven developing levels, arbitrary execution of power and overlapping IT investment. Since most regions have insufficient funds, the information center will have trouble in balancing the interests gained from informatization construction between different departments; as a result, it may even evolve into a contender for project funding; as for colleges, they will not be able to discover the best IT practices for a larger scale use; what's worse, no one at colleges is aware how much money has been invested in informatization or in which aspects. Therefore, in financial constraints, no one knows how to allocate the limited funds, resulting in a compressed investment in informatization.

The business structure of information center is unclear. Most vocational colleges imitate undergraduate institutions in building their informatization facilities. As is known to all, undergraduate institutions are expected to train knowledge-based, discipline-based, research-based and creative talents, and they focus on the interaction between teaching and scientific research, while vocational colleges target at training highly skilled and application-oriented talents. Different training goals generate different institutional settings. For example, undergraduate institutions are equipped with computing centers that attach equal importance to both teaching and research, and modern technical education centers that integrate teaching, teaching assistance and management, which are rarely found in vocational colleges.

In undergraduate institutions, the information centers have clear business modules, complete staff, and definite divisions of responsibilities. At present, the staffing of the information centers in vocational colleges is directly related to the attention paid by their management, their demand for informatization, and their investment. Each college has its own features; some are equipped with 3 
to 5 personnel, while some have dozens. Certain information centers may impede their staff to give play to their advantages or force one person to take several positions concurrently, due to their unclear business structure and unreasonable duty division: the facilitators of digital campus, coordinators of teaching application and constructers of network facilities. He would be too busy to guarantee a desirable performance outcome.

The examination and evaluation system is inadequate. The information centers of vocational colleges serve as both manager and executor, with a double identity of "player" and "referee". They are given multiple powers and responsibilities in college-level IT projects as well as the generation, audition, decision-making, implementation and supervision in connection to the budget programs, which shows a lack in group involvement and IT framework.

In consequence, vocational colleges need an immediate establishment of an appropriate examination and evaluation system, to understand their informatization level in a timely manner, guide and promote a rapid and healthy development from a macro perspective, and to provide a quantitative basis for planning; meanwhile, it helps to seize the key emphasis and weak links in work, and thus to gain a definite purpose. For certain IT projects implemented with aid from enterprises, stage monitor may be put in place, out of the consideration of leak filling.

\section{Reconstruction of Rational Informatization Mechanism}

Vocational colleges shall strengthen CIO duties and responsibilities, build an informatization leader team, establish an appropriate examination and evaluation system, enlighten the business relationships of the information center and clearly shape thoughts from the architectural aspect.

Strengthen the CIO duties and responsibilities of the senior management. The construction and application of informatization could be dated back to a very early age in many world class universities, which achieved outstanding results in their information structuring and management function building. One of the most effective methods is to establish a CIO mechanism, and it has been proved to be a successful model for informatization structure construction in colleges and universities.

Despite the increasing efforts paid by vocational colleges to information construction, the CIO system is still rarely built up amongst the senior management. Most colleges assign their vice-presidents to assume such responsibilities, who are in charge of logistics, teaching or research. As said in a famous Chinese expression "Specialists require focused practices", yet most of such vice-presidents are non-IT majors, and are occupied by considerable strategic tasks, they may spare merely limited energy on informatization. As a result, they will subconsciously shift some CIO planning and management duties to information centers.

Although the senior management in charge of informatization should stay away from concrete affairs, they are still, as a key link among all stakeholders of the IT domains, supposed to lead, monitor and coordinate all relationships in the information developing process from a strategic perspective. Their main responsibilities include: coordinating IT-related personnel, managing the use of budget and funds, and enhancing the effectiveness of IT investment; observing the actual requirements of the college, to plan for the future development of the campus informatization; rationally smoothing the IT-related organizational structure, such as information center, test center, modern technical education center and registry; supporting the professional development of all IT personnel, and promoting the best IT practices; adjusting the strategies and implementing prompt adaptive measures to the imperfect business management procedures, based on the changes of informatization, to provide policy support for the whole campus in the informatization, etc.

Set a leader team for informatization construction. A leader team for informatization construction represents CIO's think tank and the widening participation of all groups. To ensure the democracy of informatization-related planning, investment and decision making, the team members range from director representatives of all departments, professor representatives, external experts, to business representatives; the members analyze and submit the IT demand of their own department, determine the investment proposal, and form an informationized decision-making mechanism, including recommendation of team members, review and discussion led by CIO amongst team 
members, decision made by $\mathrm{CIO}$ and school board. The participation of external experts, enterprises and other groups, as well as the informationized supervision and construction, sets a real benchmark for success and failure.

The major responsibilities of the leader team include: approach to concrete affaires, submit and screen the budget proposals of each department, and enable the informatization construction to be more widely recognized and supported; assist CIO to identify the strategic direction, priority developing projects and fund allocation in the course of informatization; break through the situation of arbitrary authorities, avoid repeated projects and optimize the sharing of quality IT resources; evaluate and supervise informatization projects, and provide support for the implementation and services of the information center; assist the CIO to formulate informatization-related policies and regulations. It shall serve as a supporting department for the planning, management, coordination and supervision of informatization, and set up a forum for IT matters on the campus.

Clarify the business structure of the information center. Currently, due to the different scales, attentions paid by the management and demands for informatization, information centers are equipped with various numbers of personnel who are responsible for completing all information services and technical supports under the leadership of the head of the center. Today, many information centers are positioned as both informatization planner and service provider, while they will be more inclined to service functions in the future.

Compared with undergraduate institutes, vocational colleges are more concerned about the application. Relatively weaker in R\&D, they mostly purchase teaching and management system (or have enterprises carry out customized development). Their internal structure was not well defined. However, with the increased investment in informatization, the business volume augments as well, and the information center begins to reconstruct their internal business structure (Table 1).

(Table 1: Business and Responsibility Division of Information Center)

\begin{tabular}{|l|l|}
\hline \multicolumn{1}{|c|}{ Name of Department } & \multicolumn{1}{|c|}{ Major Responsibilities of Each Department } \\
\hline $\begin{array}{l}\text { Technical Services for } \\
\text { Users }\end{array}$ & $\begin{array}{l}\text { Personal technical support for professors on campus, such as computer } \\
\text { maintenance and software installation, etc. }\end{array}$ \\
\hline $\begin{array}{l}\text { Informatization } \\
\text { Teaching Services }\end{array}$ & Technical support for on-line students \\
\hline $\begin{array}{l}\text { Informatization } \\
\text { Management Services }\end{array}$ & $\begin{array}{l}\text { Support for the application system of public service department, quality } \\
\text { control, product control, distribution of management manual and other } \\
\text { services }\end{array}$ \\
\hline $\begin{array}{l}\text { Infrastructure } \\
\text { Maintenance }\end{array}$ & $\begin{array}{l}\text { Maintenance of networks and servers, etc. to guarantee smooth flow of } \\
\text { network facilities }\end{array}$ \\
\hline
\end{tabular}

A clear division between internal members is mandatory; however, we all know that software functions on hardware, so it is impossible to strictly define between different business modules. Therefore, the best performance comes out of a harmonious cooperation and coordination of all members.

In regard to the proportion between the personnel of each module and the student/teacher number of the college, there is no clear view at home and abroad yet. In contrast, as the students and teachers grasp better in IT, their ability grows in solving problems, and fewer personnel will be needed to provide technical support; with the deployment of Metro Card business and the in-depth application of all relevant business modules, more personnel shall be needed for informatization management; the staff number for informatization teaching services shall be determined in accordance with the duty division of registry and all other departments. 


\section{Enlightenment from Construction of Informatization Mechanism}

A reasonable informatization mechanism covering a multiple-group decision-making system and a responsibility framework may effectively improve the level and performance of informatization, secure and balance the interests of all groups. Nevertheless, we also know that it is inside an organization with decades and even centuries of culture foundation that vocational colleges implement their reports, which equals a revolution to the IT resource allocation amongst the stakeholders within the colleges, and can be regarded a cultural change in their original work pattern, work attitude and work abilities. All system change will incur some inevitable resistance, which we are ready to fight for years, as it is obvious that each step forward involves many stakeholders, who may all slow down the process.

In addition, compared with other business, informatization construction has just got started, without forming a solid cultural and institutional barrier yet, so the resistance is still considerably less if we carry out a reform over its governance. Therefore, in certain demonstration vocational colleges, the management would expect to restructure other internal domains with the same methods. Informatization reform can serve a starting point for further governance reform in colleges, which may be the underlying cause why so many leaders spend so many efforts on the reform of informatization mechanism.

\section{References:}

[1] Liu Yonggui, Promoting College Informatization Construction via IT Governance [J], Open Education Research, 2010.2:107-11

[2] Cheng Cong, Problems \& Countermeasures in Informatization Construction of Vocational Colleges [J], Chinese Vocational Education, October 2009

[3] Speech by Lu Xin on the closing ceremony of "Digital Cup - National Informatization Teaching Contest of Secondary Vocational Schools 2011", December 1, 2011 